\title{
FEEDING HABITS AND MORPHOMETRY OF DIGESTIVE TRACTS OF Geophagus brasiliensis (OSTEICHTHYES, CICHLIDAE), IN A LAGOON OF HIGH TIBAGI RIVER, PARANÁ STATE, BRAZIL
}

\section{HÁBITO ALIMENTAR E MORFOMETRIA DO TRATO DIGESTÓRIO \\ DE Geophagus brasiliensis (OSTEICHTHYES, CICHLIDAE), EM UMA LAGOA DO ALTO RIO TIBAGI, PARANÁ, BRASIL}

Marcos Flávio P. G. de Moraes', Ivana de Freitas Barbola², Luis Fernando Duboc ${ }^{3}$

1 Universidade Federal de Alagoas - CCBi, Departamento de Morfologia, Maceió, AL, Brasil; e-mail: marcospgm@yahoo.com.br.

2 Autor para contato: Universidade Estadual de Ponta Grossa - UEPG, Campus em Uvaranas, Departamento de Biologia Geral, Ponta Grossa, PR, Brasil; (42) 220-3129 / 220-3126; e-mail: barbola@interponta.com.br

3 Museu Capão da Imbuia, Curitiba, PR, Brasil; e-mail:Ifduboc@uol.com.br.

Recebido para publicação em 10/11/2003

Aceito para publicação em 04/03/2004

\begin{abstract}
Feeding spectrum of Geophagus brasiliensis (Osteichthyes, Cichlidae) stomach contents were analysed and morphometry of digestive tract are investigated, in Lagoa Dourada, Ponta Grossa, Paraná State, Brazil. A total of 83 specimens were captured between April 1993 and April 1994. From each specimen, the following measurements/data were determined: total and standard length, length of intestine and abdominal cavity, intestinal coefficient (IC = 1,59), celomatic coefficient $(\mathrm{CC}=0,36)$ and the relationship between intestinal length and celomatic cavity length $(\mathrm{il} / \mathrm{cc}=4,60)$. G. brasiliensis is an omnivorous species, and insects represented $46.21 \%$ of the total volume of their diet. Ephemeroptera, Odonata, Trichoptera and Diptera larvae were predominant, compounding the largest feeding indices. The intestine is a moderately coiled tube, with intestinal folds following a "N" shape.
\end{abstract}

Key words: Cichlidae, Geophagus brasiliensis, feeding habit, morphometry.

\section{RESUMO}

O espectro alimentar de Geophagus brasiliensis (Osteichthyes, Cichlidae) e a morfometria do trato digestório foram investigados, na Lagoa 
Dourada, em Ponta Grossa, estado do Paraná, Brasil. De abril de 1993 a abril de 1994, foram capturados 83 exemplares. De cada um deles, as seguintes medidas foram tomadas: comprimento total e padrão, comprimento do intestino e da cavidade abdominal, coeficiente intestinal (IC $=1,59)$, coeficiente celomático (IC $=0,36)$ e a relação entre comprimento intestinal e comprimento da cavidade celomática (il/cc = 4,60). G. brasiliensis é uma espécie onívora, sendo o item insetos muito importante na sua dieta, representando 46,21\% do volume total. Ephemeroptera, Odonata, Trichoptera e larvas de Díptera foram predominantes, constituindo os maiores índices alimentares em sua dieta. O intestino é um tubo moderadamente enovelado, com as alças intestinais apresentando aproximadamente a forma de " $\mathrm{N}$ ”.

Palavras chave: Cichlidae, Geophagus brasiliensis, hábito alimentar, morfometria

\section{Introduction}

Geophagus brasiliensis (Quoy and Gaimard, 1824), known as "acará", belongs to the family Cichlidae and is distributed from the Amazon Basin to Rio da Prata (Fowler, 1950; Axelrod and Schultz, 1955). It presents solitary behavior, swimming in stocking water or close to the bottom of the standing water, always during daylight (Uieda, 1984; Costa, 1987; Sabino and Correa-Castro, 1990). G. brasiliensis denote omnivorous regimen, with high incidence of autochthonous items as insects and microcrustaceans (Uieda, 1984; Costa, 1987).

The main studies about feeding habit of the acará were done by Nomura and Carvalho (1972); Barbieri and Santos (1980), at the Lobo dam; Schroeder-Araújo (1980), at the High Tietê River; Sabino and Correa-Castro (1990), at a stream of Atlantic Forest; Meschiatti (1992), at a marginal pond of the Mogi-Guaçu River; Costa (1987) in a stream at Mato Grosso State; Gealh-Escobar (1991) in the Alagados dam, at Paraná State; and Estevão et al. (1999), in a reservoir of AHE Serra da Mesa, at Goiás State.

According to Lazzaro (1991), omnivoria changes during the species ontogenesis, and specimens smaller than $40 \mathrm{~mm}$ eat mostly insects larvae, mainly Chironomidae, while specimens larger than 40mm have a more diversified diet including plankton, debris and benthos.
This study aims to elucidate the trophic ecology of $G$. brasiliensis, through feeding compounds evaluation of the population of Lagoa Dourada, at Paraná State, and their modifications along the individual development.

\section{Material and Methods}

\subsection{Study area}

Lagoa Dourada pond ( $\left.25^{\circ} 15^{\prime} \mathrm{S}, 50^{\circ} 02^{\prime} \mathrm{W}\right)$ is a lagoon of high Tibagi River and is located in the Vila Velha State Park, at Ponta Grossa, Paraná State, southern Brazil, 812m high of altitude (Fig. 1). It is almost 200m at its widest axis and has maximum depth of 5.4m (Moro and Bicudo, 1998). It is part of Furnas Complex, constituted mainly by sandstone (Soares, 1989).

According to Maack (1981) and Soares (1989), Lagoa Dourada is a dolina in a senility process, almost filled up with muddy and sandy sediments. It presents a $150 \mathrm{~m}$ drainage channel for the Guabiroba River, which is one of the first tributaries of the right margin of the Tibagi River.

\subsection{Procedure}

From April 1993 to April 1994, 83 specimen of $G$. brasiliensis were captured. For each specimen 


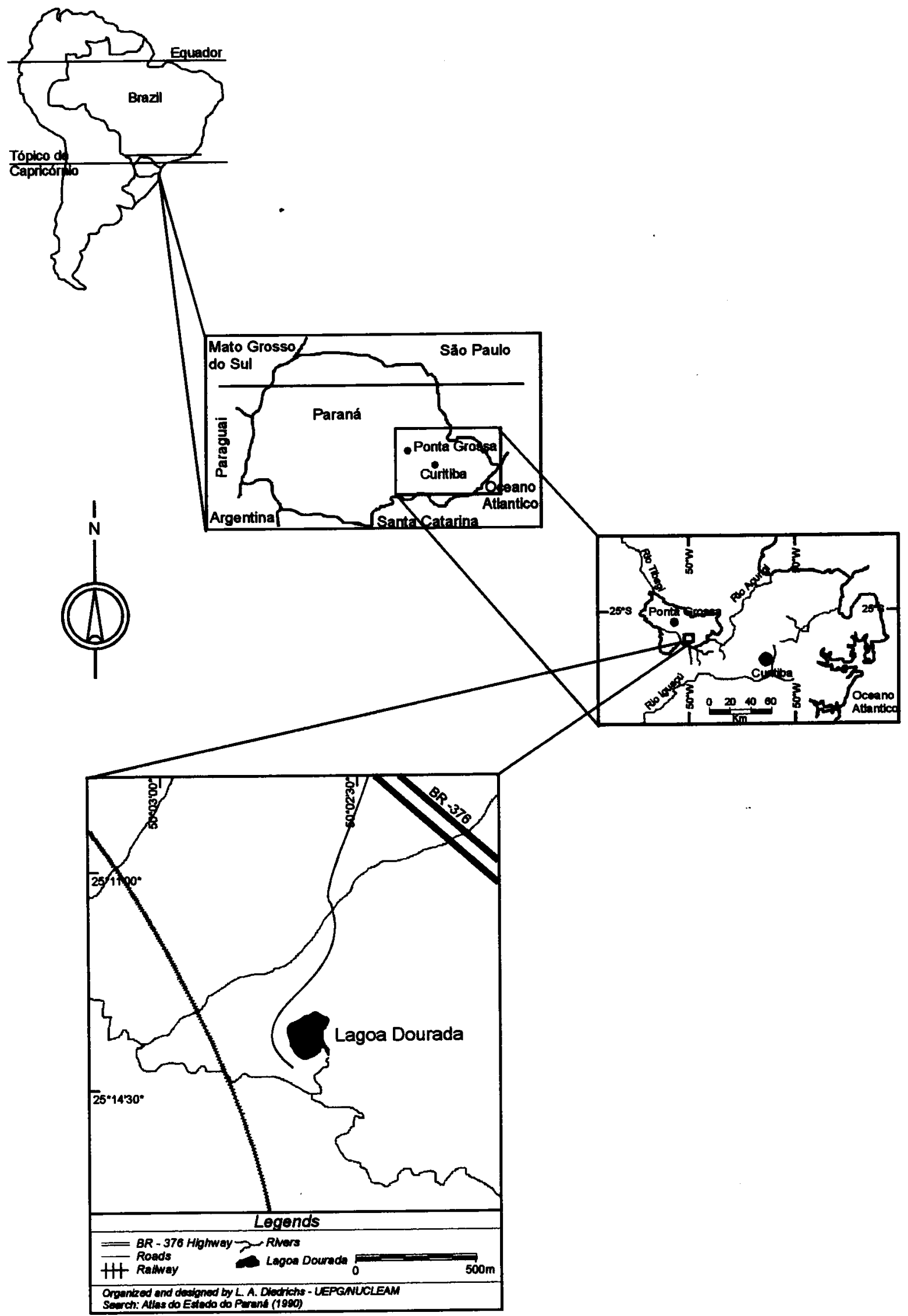

Figure 1 - Study area: Lagoa Dourada, Ponta Grossa, Paraná State, Brazil. 
was registered the total length (tl), the standard length (sl) and the total weight (tw). For total weight/ total length comparison, data were plotted on a graph with curve adjustment to the function tw = a.tl ${ }^{\mathrm{b}}$ (Hoffman and Vieira, 1977). The angular coefficient b is related to the type of the individuals' growth. For values of 3.0 it is said that the growth is isometric; for values larger or smaller than 3.0, the growth is alometric (Le Cren, 1951).

The digestive tract was extracted and fixed in $10 \%$ formaldehyde. Later, calliper measurements of the celomatic cavity (cc) were taken, with an accuracy of $0.05 \mathrm{~mm}$, as well the intestinal length (il) (in $\mathrm{cm}$ ). From the obtained data the celomatic coefficient (CC) and the intestinal coefficient (IC) was determined (Gneri and Angelescu, 1951).

The feeding items were identified using a specific bibliography and by means of the

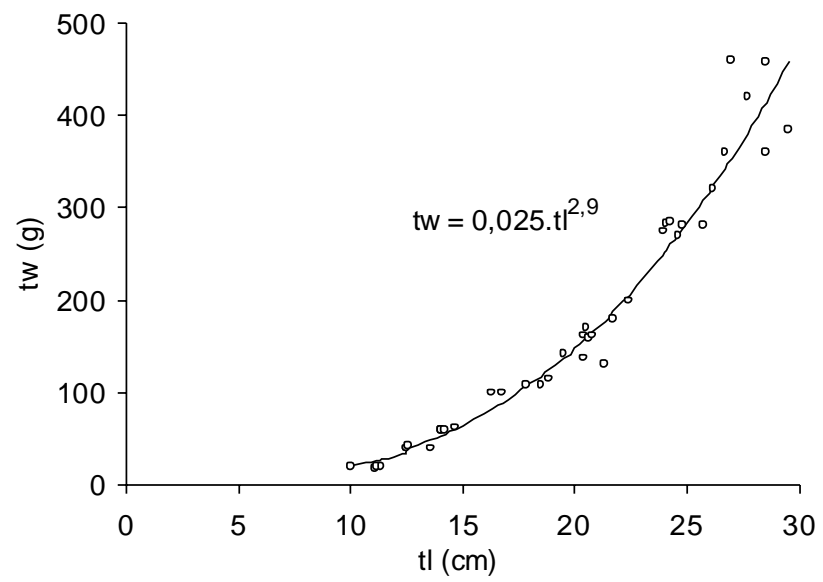

consultation of experts, when necessary. The frequency and occurrence of feeding items, their volume and the feeding indices were analyzed according to Hynes (1950) and Kawakami and Vazzoler (1980). Trophic similarity among the different size classes and consequently, different phases of the individual development within a population, were obtained from Morisita index modified, with groupings obtained by the UPGMA (unweighted pair group method using arithmetic averages) (Rohlf, 1994).

\section{Results and Discussion}

The relationship between weight (tw) and the total length (tl) are presented in Fig. 2. The value of

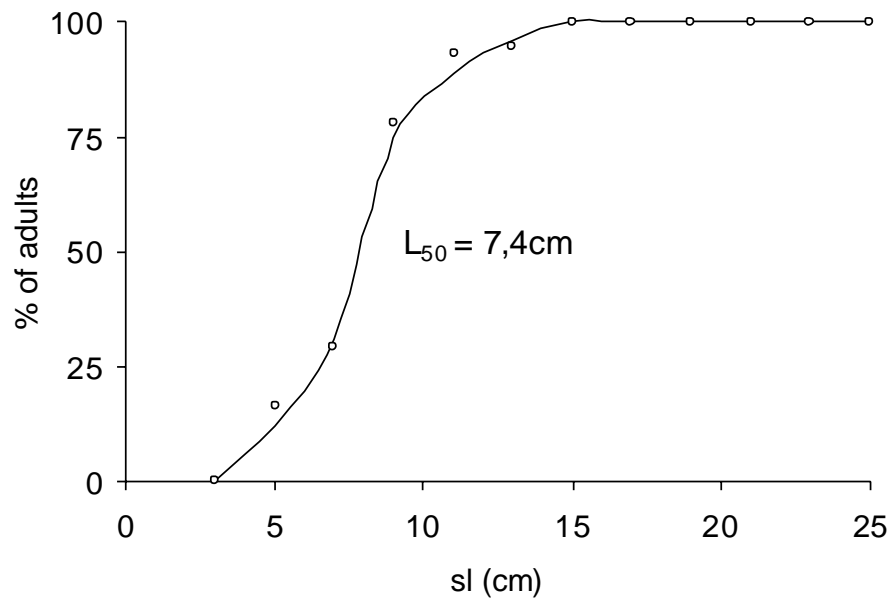

Figure 2 - Comparison between total weigh (tw) (in g) and total length (tl) (cm) of Geophagus brasiliensis.

the parameter "b" for G. brasiliensis obtained in this work (2.93) is similar to that observed prior in the lentic environments of São Paulo by Nomura and Carvalho (1972) and Barbieri and Santos (1980), and of Paraná, by Geahl-Escobar (1991) which describes for this taxon an isometric growth with no significant differences for males and females. Regarding this, the authors state that the differences found between the sexes were not biologically important, attributing them to environmental variations and to the biogenetic aspects of the species.

\subsection{Diet}

Geophagus brasiliensis presented a great feeding diversity (Tab. 1). Insects represented $46.21 \%$ of the total volume of their diet. Ephemeroptera, Odonata, Trichoptera and Diptera larvae were predominant, compounding the largest feeding indices. Next were Gastropoda (12.06\%), fragments of Arthropoda (8.54\%), unidentified/ digest material (6.36\%), vegetal fragments (4.19\%), sediments $(3.85 \%)$, algae $(3.85 \%)$, and thecamoebians (3.51\%). 
Table 1 - Composition of the feeding diet of Geophagus brasiliensis: occurrence (ni), frequency (Fi) and volume (Vi) of each item and feeding indexes (IAi) of the analysed specimens of Lagoa Dourada, Paraná.

\begin{tabular}{lc|c|c|c|c}
\hline \multicolumn{1}{c}{ FEEDING ITEM } & $\mathbf{N i}$ & $\mathbf{F i}$ & $\mathbf{V i}$ & $\mathbf{F i . V i}$ & $\mathbf{I A i}$ \\
\hline Ephemeroptera (youth) & 72 & 86,74 & 12,06 & 1046,08 & 0,273 \\
Gastropoda & 72 & 86,74 & 12,06 & 1046,08 & 0,273 \\
Odonata (youth) & 70 & 84,33 & 11,72 & 988,35 & 0,258 \\
Trichoptera (youth) & 65 & 78,30 & 10,88 & 851,90 & 0,222 \\
Artropoda fragments & 51 & 61,44 & 8,54 & 524,70 & 0,137 \\
Diptera (youth) & 50 & 60,20 & 8,37 & 503,87 & 0,131 \\
Vegetal fragments & 25 & 30,12 & 4,19 & 126,20 & 0,033 \\
Filamentous algae & 23 & 27,71 & 3,85 & 106,68 & 0,028 \\
Tecameba & 21 & 25,30 & 3,51 & 88,80 & 0,023 \\
Bivalve & 20 & 24,09 & 3,35 & 80,70 & 0,021 \\
Ostracoda & 10 & 12,04 & 1,67 & 20,11 & 0,005 \\
Nematoda & 9 & 10,84 & 1,51 & 16,37 & 0,004 \\
Coleoptera (ad.) & 8 & 9,63 & 1,34 & 12,90 & 0,003 \\
Orthoptera (ad.) & 6 & 7,22 & 1,00 & 7,22 & 0,002 \\
Seeds & 5 & 6,02 & 0,83 & 4,99 & 0,001 \\
Oligochaeta & 5 & 6,02 & 0,83 & 4,99 & 0,001 \\
Cladocera & 5 & 6,02 & 0,83 & 4,99 & 0,001 \\
Hymenoptera & 4 & 4,81 & 0,67 & 3,22 & - \\
Hemiptera (ad.) & 1 & 1,20 & 0,17 & 0,20 & - \\
Fish scales & 1 & 1,20 & 0,17 & 0,20 & - \\
Sediment & 23 & 27,71 & 3,85 & 106,68 & 0,028 \\
Non biological fragments & 13 & 15,66 & 2,18 & 34,14 & 0,009 \\
Non identif./digest & 38 & 45,78 & 6,36 & 291,16 & 0,075 \\
\hline Total & 597 & - & 100,00 & 3831,11 & - \\
\hline & & & & & \\
& & & & & \\
& & & & & \\
\end{tabular}

The similarity of diets among the different size classes (Fig. 3 e 4), showed that individuals ranging between $2.6 \mathrm{~cm}$ and $6.0 \mathrm{~cm}$ of length (class I, representing the younger population), consumed mainly smaller items such as fragments of Arthropoda (22.20\%), Diptera larvae (20.60\%) and sediments (15.90\%); individuals ranging in length from $6.0 \mathrm{~cm}$ to $19.6 \mathrm{~cm}$ (classes II, III and V, comprising a small proportion of youths and most of adults) shared mainly Ephemeroptera larvae, Odonata, Trichoptera and Gastropoda (items of a larger size), at the level of $73.00 \%$ of similarity (the classes III and V still consume the bivalve item, which is in $80 \%$ of their diet). Adults of the classes VI and VII have in common consumption of large quantities of Gastropoda, Odonata and
Ephemeroptera larvae.

The ingested insects (youth and adults) and insect fragments represented a significant portion of the feeding diet of $G$. brasiliensis. For Corbet (1961) the insects are, apparently, don't require great specializations from their predators, being the principal consumed food item.

Several authors reported feed compositons of G. brasiliensis similar to the one obtained in this work. Aquatic insects, debris, algae, vegetal fragments, sediments and seeds of Dicotiledonea are decribied by Barbieri and Santos (1980), SchroederAraújo (1980), Sabino and Correa-Castro (1990) and Estevão et al. (1999) as principal components of the diet of this species 


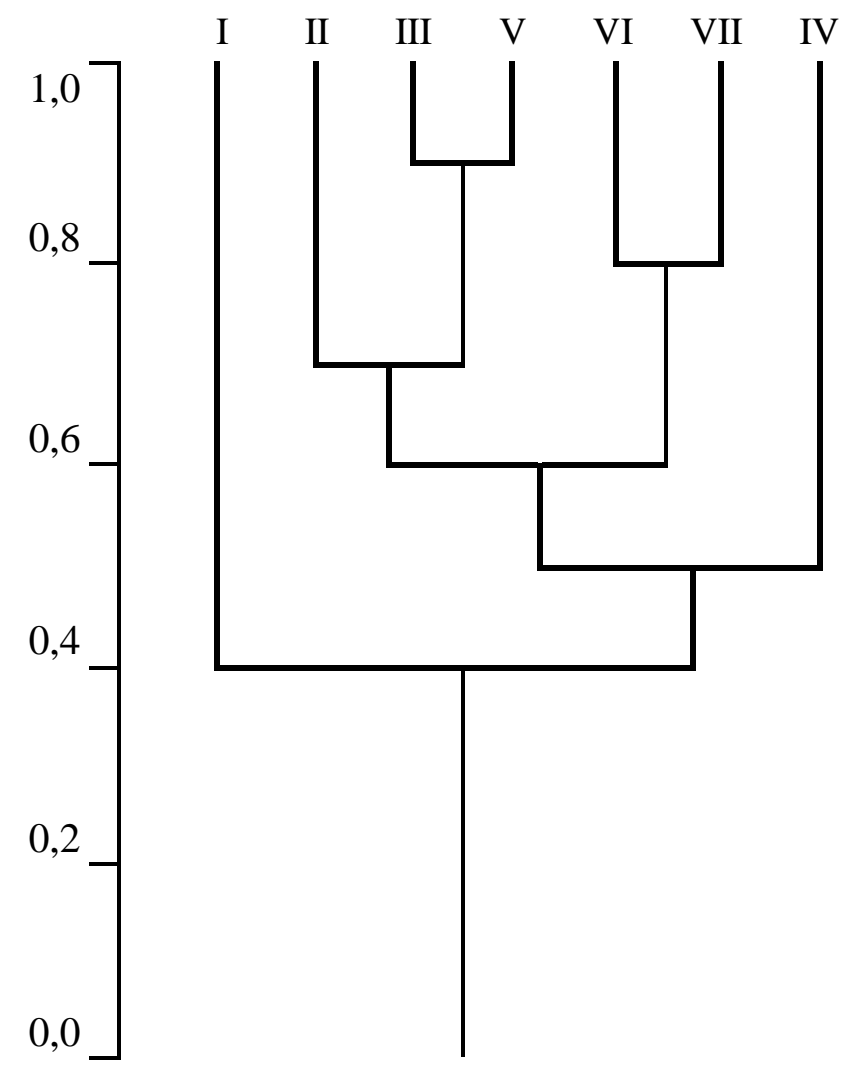

Figure 3 - Cluster analysis of individual size of $G$. brasiliensis, according their feeding habits. (class $\mathrm{I}=2,6-6,0 \mathrm{~cm}$; II $=6,1-9,4 \mathrm{~cm} ; \quad$ III $=9,5-12,8$ $\mathrm{cm}$; IV = 12,9-16,2 cm; V = 16,3-19,6 cm; VI = 19,7-23,0 cm; VII =.23,1-26,7 cm).

\subsection{Biometric relationships among the lengths of the body, the intestine and the celomatic cavity}

During their development many fish experience changes in their feeding habits, in their behavior of food capture and in their habitat. Modifications in the diet frequently result from morphologic alterations in the feeding structures that tend toward the improved capture efficiency of larger or denser particles (Macneill and Brandt, 1990). The feeding tube morphology reflects the feeding trends of the species, determining their plasticity (Fugi and Hahn, 1991). Macroscopic and microscopic structures of the several organs of the digestive tract are closed related to the nature of the food and the form in which it is ingested. This depends first on the organs involved in the capture and assimilation of the food and of the feeding behavior of the fish, and second on the composition and amount of available food (Pillay, 1952; Chaves and Vazzoler, 1984).

The intestinal coefficients (IC) and celomatic coefficients (CC) are morphometric indicators that allow the establishment of the individual and specific variations correlated with feeding habits, age and degree of body development (Angelescu and Gneri, 1949), to an effort to determine the relationships of the measurements with the corresponding anatomical adaptations.

Being a predominantly omnivorous species (Nomura and Carvalho, 1972; Schroeder-Araújo, 1980; Sabino and Corrêa-Castro, 1990), G. brasiliensis presented an IC of 1.59. According to Jacobshagen (1937) apud Bertin (1958) this relationship between the intestinal and corporeal length varies among the carnivores from 0.2 to 2.5 , among the omnivores from 0.6 to 0.8 , and the herbivores from 0.8 to 15.0 . This would allow classify the diet of $G$. brasiliensis in any of these categories. Kappor et al. (1975) point out, however, that the intestinal length sensibly responds to changes in feeding conditions, and the mutual dependence between the intestinal length and the feeding habits happens not only in the adult phase, but also during the individual's development. The carnivorous species, for instance, present the shortest intestines, while in omnivorous the length depends directly on the proportions of the components of the diet.

The celomatic cavity of $G$. brasiliensis is relatively small $(C C=0.36$ ), when compared to other predator species as Hoplias malabaricus, or to iliophagous such as Prochilodus lineatus (Moraes and Barbola, 1995; Moraes et al. 1997), whose cavity completely filled with digestive organs and gonads.

The relationship il/cc obtained (4.60) applied to the coefficient of Suyehiro (1942), allows to classify the pattern of rolling up of the intestinal loops of $G$. brasiliensis as a derived arrangement in the "N" shape. According to this author, the arrangement of the intestinal loops shows a dependence on both of the size of the celomatic cavity and on the intestinal length. The presence of a pattern confirms the existence of a relationship 

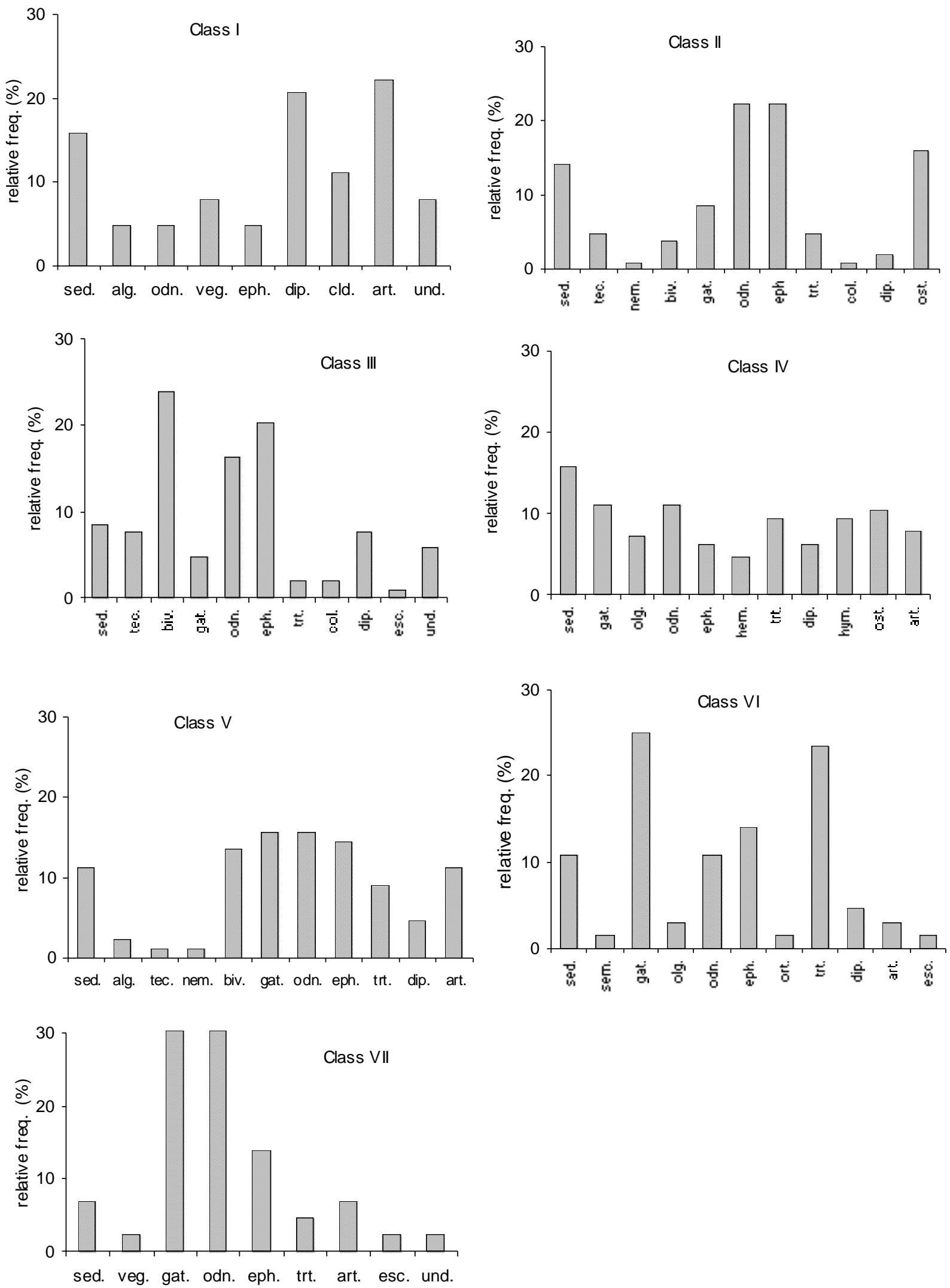

Figure 4 - Composition of the feeding diet of the different classes of size of G. brasiliensis. alg. = filamentous algae; art. = artropoda fragments; biv. $=$ Bivalve; cld. $=$ Cladocera; col. $=$ Coleoptera; dip. $=$ Diptera; $\mathbf{e p h}$. $=$ Ephemeroptera; esc. $=$ fish scales; gat. $=$ Gastropoda; hem. $=$ Hemiptera; $\mathbf{~ h y m . ~}=$ Hymenoptera; nem. $=$ Nematoda; odn. $=$ Odonata; olg. $=$ Oligochaeta; ost. $=$ Ostracoda; sed. $=$ sediments; sem. $=$ seeds; tec. = tecameba; trt. = Trichoptera; und. $=$ unidentified; veg. = vegetal fragments. 
influenced by body shape, individual growth and feeding habits.

\section{Acknowledgements}

The authors would like express their acknowledgments to the IAP (Environmental Institute of Paraná) for facilitations on the field work; to Julio Garavello (UFSCar) and Paulo H. Lucinda (UNITINS) for the species identification and to Fernando Chiavenatto and Luciana A. Gebrim for the help in the field works.

\section{REFERENCES}

ANGELESCU,V.; F.S. GNERI. Adaptaciones del aparato digestivo al regimen alimenticio in algunos peces del Rio de la Plata. Rev. Inst. Nac. Invest. Mus. Argent. Cienc. Nat. Ciencias Zoológicas, v. 1, p. 161-272, 1949.

AXELROD, H.R.; L.P. SCHULTZ. Handbook of Tropical Aquarium Fishes. New York, Mac Graw-Hill, 1955.

BARBIERI, G.; E.P. SANTOS. Dinâmica da Nutrição de Geophagus brasiliensis (Quoy \& Gaimard, 1824), na Represa do Lobo, Estado de São Paulo, Brasil. Cienc. Cult., v. 32, p. 87-89, 1980.

BERTIN, L. Apareil digestif. In: P.P. Grassé (ed.). Traité de Zoologie. Ed. Masson, Paris, 1958.

CHAVES, P.T.C.; G. VAZZOLER. Aspectos Biológicos de Peixes Amazônicos. III. Anatomia Microscópica do Esôfago, Estômago e Cecos Pilóricos de Semaprochilodus insignis (Characiformes: Prochilodontidae). Acta Amazônica, v. 14, p. 343-353, 1984.

CORBET, P.S. The food of non-cichlid fishes in the Lake Victoria Basin, with remarks on their evolution and adaptation to lacustrine condition. Proc. Zool. Soc., v. 136, p. 1-101, 1961.

COSTA, W.J.E.M. Feeding habits of a fish community in a tropical coastal stream, Mato Grosso, Brasil. Stud. Neotrop. Fauna Environ., v. 22, p. 145-153, 1987.

ESTEVÃO, V.N.A.; R.A. REIS; E.P. CARAMASCHI. Alimentação de Geophagus sp. no período anterior à formação do reservatório do AHE Serra da Mesa - GO. In: Encontro Brasileiro de Ictiologia, 13, 1999, São Carlos. Resumos...

FOWLER, H.W. Os peixes de água doce do Brasil. Arq. Zool. Estado São Paulo, v. 6, p. 205-404, 1950.

FUGI, R.; N.S. HAHN. Espectro alimentar e relações morfológicas com o aparelho digestivo de três espécies de peixes comedores de fundo do Rio Paraná, Brasil. Rev. Bras. Biol, v. 5l, p. 873-879, 1991.

GEALH-ESCOBAR, A.M. N. Aspectos da biologia e da estrutura da comunidade de peixes da represa Alagados, Ponta Grossa, PR. Curitiba, 1991. 96 p. Thesis of Master, Universidade Federal do Paraná.

GNERI, F.S.; V. ANGELESCU. La nutrición de los peces iliofagos em relación com el metabolismo general del ambiente acuático. Rev. Inst. Invest. Mus. Argent. Cienc. Nat. Cien. Zool., v. 2, p. 1-44, 1951.

HOFFMAN, R.; S. VIEIRA. Análise de regressão: uma introdução à econometria. HUCITEC/EDUSP, São Paulo, 1977.

HYNES, H.B.N. The food of fresh water sticklebacks (Gasterosteus aculeatus and Pygosteus pungiteus) with a review of methods used in studies of food of fishes. J. Anim. Ecol., v. 19, p. 36-58, 1950.

KAPPOR, B.G.; H. SMITH; I.A. VERIGINA. The alimentary canal and digestion in teleosts. Adv. mar. Biol., v. 13, p. 109-239, 1975.

KAWAKAMI, E.; G. VAZZOLER. Método gráfico e estimativa de índice alimentar aplicado ao estudo de alimentação de peixes. Bol. Inst. Oceanogr., v. 29, p. 205-207, 1980.

LAZZARO, X. Feeding convergence in south american and african zooplanktivorous cichlids Geophagus brasiliensis and Tilapia rendalii. Environ. Biol. Fishes, v. 31, p. 283-293, 1991.

LE CREN, E.D. The lenght-weight relationship and seasonal cycle in gonad weigh and condition in the perch (Perca fluviatis). J. Anim. Ecol. v. 2092, p. 201-219, 1951.

MAACK, R. Geografia física do Paraná. Curitiba, Olympio. 325 p., 1981

MACNEILL, D.B.; S.B. BRANDT. Ontogenetic shifts in gillraker morphology and predicted prey capture efficiency of the alewife Alosa pseudoharengus. Copeia, v. 1, p. 164-171, 1990.

MESCHIATTI, A.J. 1992. Alimentação da comunidade de peixes de uma lagoa marginal do Rio Mogi-Guaçu, SP. São Carlos, 1992. 123 p. Thesis of Master, Universidade Federal de São Carlos.

MORAES, M.F.P.G.; I.F. BARBOLA. Hábito alimentar e morfologia do tubo digestivo de Hoplias malabaricus (Osteichthyes, Erythrinidae) da Lagoa Dourada, Ponta Grossa, Paraná, Brasil. Acta Biol. Par., v. 24, p. 1-23, 1995.

MORAES, M.F.P.G.; I.F. BARBOLA; E.A.C. GUEDES. Alimentação e relações morfológicas com o aparelho digestivo do «curimbatá», Prochilodus lineatus (Valenciannes) (Osteichthyes, Prochilodontidae), de uma lagoa do sul do 
Brasil. Rev. bras. Zool., v. 14, p. 169-180, 1997.

MORO, R.S.; C.E.M. BICUDO. Flutuações climáticas no Pleistoceno tardio e Holoceno na Lagoa Dourada, Estado do Paraná, Brasil. Acta Limnologica brasiliensia, v. 10, p. 4758, 1998.

NOMURA, H.; S.C. CARVALHO. Biologia e número de rastros do acará, Geophagus brasiliensis (Pisces, Cichlidae). Rev. Bras. Biol., v. 32, p. 169-176, 1972.

PILLAY, T.V.R. A critique of the methods of study of food of fishes. J. Zool. Soc. India, v. 4, p. 185-200, 1952.

ROHLF, F.J. NYSYS - PC. Numerical taxonomy and multivariate analysis and system (version 1.80). Exeter software. Building Setanket, New York, 1994.
SABINO, J.; R.M. CORREA-CASTRO. Alimentação, período de atividade e distribuição espacial dos peixes de um riacho da Floresta Atlântica (sudeste do Brasil). Rev. Bras. Biol., v. 50, p. 23-36, 1990.

SCHROEDER-ARAUJO, L.T. 1980. Alimentação dos peixes da represa ponte nova, Alto Tiête. São Paulo, 1980. 154 p. Thesis of Doctor, Universidade de São Paulo.

SOARES, O. Furnas dos Campos Gerais, Paraná. Scientia et Labor, Curitiba, 1989.

SUYEHIRO, Y. A study of the digestive system and feeding habits of fish. Jpn. J. Zool., v. 10, p. 1-303, 1942.

UIEDA, V.S. Ocorrência e distribuição dos peixes em um riacho de água doce. Rev. Bras. Biol., v. 44, p. 203-212, 1984. 